\title{
Harlequin syndrome in spontaneous dissection of the cervical carotid artery
}
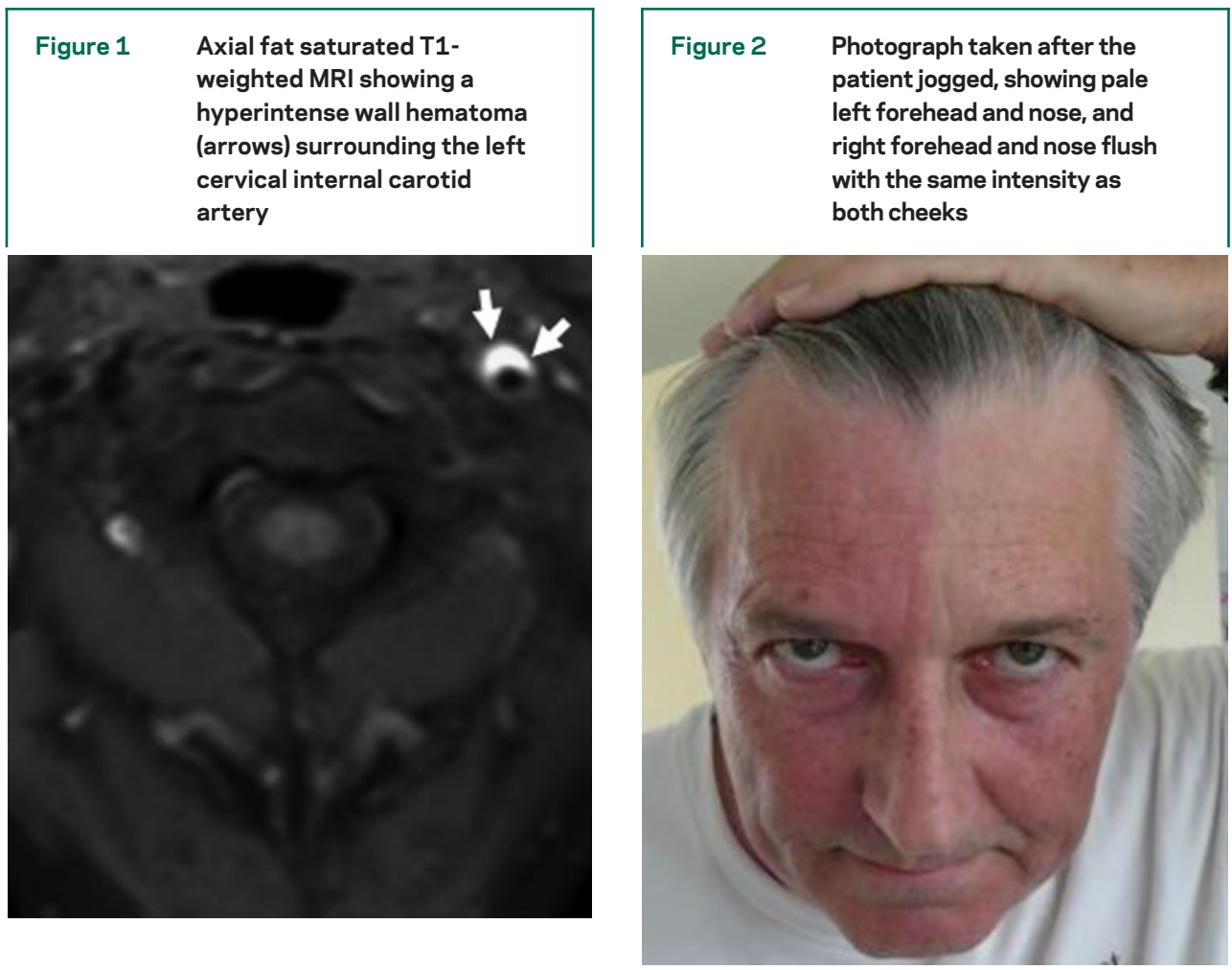

A 52-year-old previously healthy man had a spontaneous dissection of the left cervical carotid artery (figure 1) with Horner syndrome. Three months later, when the patient restarted his running training, he noticed the symptoms of Harlequin syndrome (figure 2), which consist of unilateral facial flushing and sweating. ${ }^{1}$ The Harlequin syndrome affected only the left part of the patient's face and nose, because vasomotor and sudomotor sympathetic fibers traveling along the internal carotid artery innervate just the forehead and nose. This patient shows that physicians should also consider spontaneous carotid dissection as possible etiology of Harlequin syndrome.

Hakan Sarikaya, MD, Dimitrios Georgiadis, MD, RalfW. Baumgartner, MD, Zürich, Switzerland

Disclosure: The authors report no disclosures.

Address correspondence and reprint requests to Dr. Ralf W. Baumgartner, Department of Neurology, University Hospital, Frauenklinikstrasse 26, CH-8091 Zürich, Switzerland; ralf.baumgartner@usz.ch

1. Lance JW, Drummond PD, Gandevia SC, Morris JG. Harlequin syndrome: the sudden onset of unilateral flushing and sweating. J Neurol Neurosurg Psychiatry 1988;51:635-642. 


\section{Neurology}

\section{Harlequin syndrome in spontaneous dissection of the cervical carotid artery Hakan Sarikaya, Dimitrios Georgiadis and Ralf W. Baumgartner \\ Neurology 2008;71;1459 \\ DOI 10.1212/01.wnl.0000327877.74795.d7}

\section{This information is current as of October 27, 2008}

\section{Updated Information \& Services}

References

Citations

Subspecialty Collections

Permissions \& Licensing

Reprints including high resolution figures, can be found at: http://n.neurology.org/content/71/18/1459.full

This article cites 1 articles, 1 of which you can access for free at: http://n.neurology.org/content/71/18/1459.full\#ref-list-1

This article has been cited by 1 HighWire-hosted articles: http://n.neurology.org/content/71/18/1459.full\#\#otherarticles

This article, along with others on similar topics, appears in the following collection(s):

Carotid artery dissection

http://n.neurology.org/cgi/collection/carotid_artery_dissection

Information about reproducing this article in parts (figures,tables) or in its entirety can be found online at:

http://www.neurology.org/about/about_the_journal\#permissions

Information about ordering reprints can be found online:

http://n.neurology.org/subscribers/advertise

Neurology ${ }^{\circledR}$ is the official journal of the American Academy of Neurology. Published continuously since 1951, it is now a weekly with 48 issues per year. Copyright . All rights reserved. Print ISSN: 0028-3878. Online ISSN: 1526-632X.

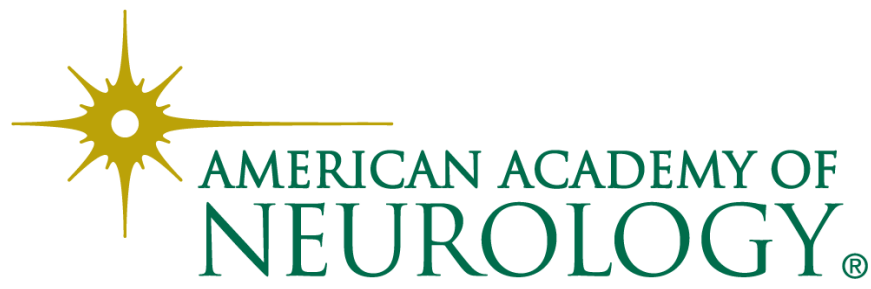

